\title{
Behavior of Nannopterum brasilianus (Gmelin, 1789) (Suliformes: Phalacrocoracidae) in an urban park in the municipality of Uberlândia, Minas Gerais State
}

\author{
Dayana Nascimento Carvalho * \\ Liliane Martins de Oliveira \\ Oswaldo Marçal Júnior \\ Laboratório de Ornitologia e Bioacústica, Universidade Federal de Uberlândia, Instituto de Biologia \\ Rua Ceará, s/n, Campus Umuarama, Bloco/sala 2D34, CEP 38400-902, Uberlândia - MG - Brasil \\ * Autor para correspondência \\ dayanancarvalho@ufu.br
}

Submetido em 09/08/2018

Aceito para publicação em 16/05/2019

\section{Resumo}

Comportamento de Nannopterum brasilianus (Gmelin, 1789) (Suliformes: Phalacrocoracidae) em um parque urbano do município de Uberlândia, estado de Minas Gerais. A modificação das paisagens pela ação antrópica, principalmente devido o processo de urbanização exercem forte pressão sobre as aves. Parques públicos e outras áreas verdes oferecem condições favoráveis para a permanência de aves nas cidades ao longo do ano. A espécie Nannopterum brasilianus (Gmelin, 1789), biguá, é uma das aves aquáticas piscívoras mais frequentes e abundantes em parques urbanos, rios e reservas. O objetivo deste trabalho foi descrever o repertório comportamental de Nannopterum brasilianus, avaliando possíveis mudanças comportamentais nas estações seca e chuvosa, em uma área urbana de Uberlândia (MG). O estudo foi conduzido no Parque Municipal do Sabiá, no período de dezembro de 2013 a novembro de 2014, totalizando 184 h de observação. Utilizou-se o método de amostragem de ponto fixo, em quatro lagoas do Parque. As observações foram realizadas no período da manhã, sendo utilizadas as técnicas animal focal e observação de todos os registros (ad libitum). Ao todo, foram obtidos 164 registros da espécie. O repertório comportamental incluiu 15 atos comportamentais, com destaque para repouso-poleiro e preening. Os comportamentos mostraram variações entre as estações do ano $\left(\chi^{2}=62,05\right.$; $\mathrm{df}$ $=14 ; \mathrm{p}<0,001$ ), sendo vôo-grupo e repouso-margem mais exibidos na estação chuvosa.

Palavras-chave: Aves aquáticas; Avifauna urbana; Biguá; Comportamento Animal; Etologia

\section{Abstract}

The modification of landscapes by anthropic action, mainly due to urbanization, exerts strong pressure on birds. Public parks and other green areas offer favorable conditions for birds in cities throughout the year. Nannopterum brasilianus (Gmelin, 1789), the Neotropic cormorant, is one of the most frequent and abundant piscivorous water birds in urban parks, rivers and reserves. The present study aimed to describe the behavioral repertoire of $N$. brasilianus and evaluated possible behavioral changes in the dry and rainy seasons, in an urban area in Uberlândia (MG). The study was conducted in Sabiá Municipal Park, from December 2013 to November 2014, totaling 184 hours of observation. The fixed-point sampling method was used, in four ponds in the park. 
Observations were made in the morning, using the focal animal and ad libitum (record of all occurrences) techniques. In all, 164 records of the species were obtained. The behavioral repertoire included 15 behavioral acts, notably perching and preening. Some behaviors varied between the seasons $\left(\chi^{2}=62.05, \mathrm{df}=14, \mathrm{p}<0.001\right)$, including flock flight and perching on the pond bank, which were displayed more in the rainy season.

Key words: Animal behavior; Ethology; Neotropic cormorant; Urban birds; Water birds

\section{Introduction}

Urbanization exerts considerable pressure on different groups of animals, especially birds because they are highly sensitive to anthropic modifications (SHERER et al., 2010). Many bird species cannot adjust to an urban environment, but others can benefit from the availability resources to feed and reproduce (HÖFLING; CAMARGO, 1999; RICKLEFS, 2016). This may explain the large occurrence of water birds in urban parks (FRANCHIN and MARÇAL-JUNIOR, 2004; RIBEIRO and FERREIRA, 2014) throughout the year (MAFIA et al., 2012).

Behavioral changes are among the most visible signs of the impact of human activity on birds, including changes in alert signs to more complex behavioral changes, such as those related to competition and predation (MØLLER; IBÁÑEZ-ÁLAMO, 2012). For instance, foraging behavior can vary in areas highly visited by humans as a response to human activity (FERNÁNDEZ-JURICIC; TELLERÍA, 2000). Another factor that can affect and direct the foraging behavior of birds is the spatial and temporal variance in the distribution of resources (MAURER, 1990).

The behavior of birds can be further modulated by seasonal variations, with the change in periods and volume of rainfall. Piscivorous species, such as some waders, can be affected by the availability of fish throughout the dry and rainy seasons. In periods of drought, when there is little rainfall and high evaporation, the water level of aquatic environments decreases, exposing a large amount of dead prey to these birds. At times with high precipitation, the water level increases, making it more difficult to forage for these species (GUIBU et al., 2007). The reproductive cycle of some bird species is more dependent on water, such as waders that undergo changes due to variations in rainy intervals, which affects the time of arrival in breeding sites and, consequently, the period of oviposition in the dry season (TELINO JÚNIOR et al., 2003). In addition, the patterns of vocalization displayed by birds, such as communication between individuals and the demarcation of territory, also vary seasonally (ANJOS, 2010) because they are dependent on ecological factors (SICK, 1997).

Nannopterum brasilianus (Gmelin, 1789), the Neotropic cormorant, is one of the most frequent and abundant water birds in green urban areas (RIBEIRO; FERREIRA, 2014). This species is widespread in Brazil and inhabits the margins of ponds, rivers, and bays. It is $63-68 \mathrm{~cm}$ long, black with brown coloration on its back, has a long slender beak with a spike at the end that makes it possible for it to capture prey, has yellow gular skin, yellow facial skin with thin white edging, and a few white feathers on the head and neck during reproduction (GWYNNE et al., 2010). This piscivorous species is quite active during the daytime and can be found isolated or collectively, which makes it easy to monitor (SICK, 1997).

Green areas in the city of Uberlândia are important places for avifauna, especially in the most adverse time of the year, the dry season (FRANCHIN; MARÇALJÚNIOR, 2004). In this context, and considering the importance of birds to the maintenance of the ecological balance of different ecosystems (including those modified by humans), mainly for their role as pollinators, dispersers and regulators of prey (SHERER et al., 2010; RICKLEFS, 2016), this study describes the behavioral repertoire of Nannopterum brasilianus and evaluates possible behavioral changes between dry and rainy seasons, in an urban area of Uberlândia, MG.

\section{Material and Methods}

\section{Study area}

The municipality of Uberlândia, Minas Gerais

State, is located in the Cerrado biome. It is 4,115,206 
$\mathrm{km}^{2}$ and has an estimated population of 676,613 inhabitants (IBGE, 2017). Currently, natural areas in this region are restricted to small fragments, isolated by intense agricultural activity and reforestation (ARAÚJO et al., 1997). The climate of the municipality is Aw (tropical of savannah) according to the Köppen climate classification. The rainy season (hot and humid summer) occurs from October to March and the dry season (cold and dry winter) is from April to September (ROSA et al., 1991).

Sabiá Municipal Park (1854’34.2”S 48¹4’05.7’W) is $1,850,000 \mathrm{~m}^{2}$ and has three fountains, seven ponds, remnants of natural vegetation (woodland and veredas, which are swampy plains between hills and rivers), as well as several areas used for leisure. The local flora is represented by approximately 300 species of native and exotic trees. The fauna includes nearly 200 species that are kept in captivity in the park's zoo (PMU, 2014), along with many species that freely roam the area. The local avifauna alone comprises more than 150 species (FRANCHIN; MARÇAL-JÚNIOR, 2004) (Figure 1).

\section{Data collection}

The field study was carried out from December 2013 to November 2014. Four ponds (out of a total of seven) were investigated in Sabiá Municipal Park
(A, B, C and D). Sampling involved the fixed-point method (BIBBY et al., 1992), which was constructed as following: three points in pond $\mathrm{A}(\mathrm{A} 1, \mathrm{~A} 2, \mathrm{~A} 3)$ and one point in the other ponds (B4, C5 and D6). The points had a fixed radius of $100 \mathrm{~m}$ and were established at a distance of at least $200 \mathrm{~m}$ from each other. Each point was sampled in 30-minute sessions, controlled with a stopwatch and divided into two steps: 15 minutes of observation, 5 minutes of interval plus 15 minutes of observation. To record the behaviors, the focal animal and ad libitum (record of all occurrences) techniques were used (ALTMANN, 1974; DEL CLARO, 2004).

Observations were made using binoculars $(8 \mathrm{x}$ $40 \mathrm{~mm}$ ) in the morning (between $06 \mathrm{~h} 00$ and $12 \mathrm{~h} 00$ ), totaling a sample effort of $184 \mathrm{~h}$. The number and height of potential perches were recorded considering the area of the pond and its surroundings, occurrence on the margin (up to $2 \mathrm{~m}$ from the point to the pond), and occurrence of agonistic interactions (intraspecific and with other piscivorous species), all within a fixed radius of $100 \mathrm{~m}$. Perches (artificial or natural structures) were quantified and measured using the Smart Measure v.1.5.11 application (Smart Tools co.) available for mobile phones. The margin of each pond was measured using the My Tracks v.2.0.9 (Google Inc.) application, also available for mobile phones. Data about temperature and rainfall in Uberlândia were obtained from the

FIGURE 1: Study area - sampling points (X): Pond A (A1, A2, A3), Pond B (B4), Pond C (C5), Pond D (D6) - (Source: Google Earth 2018).

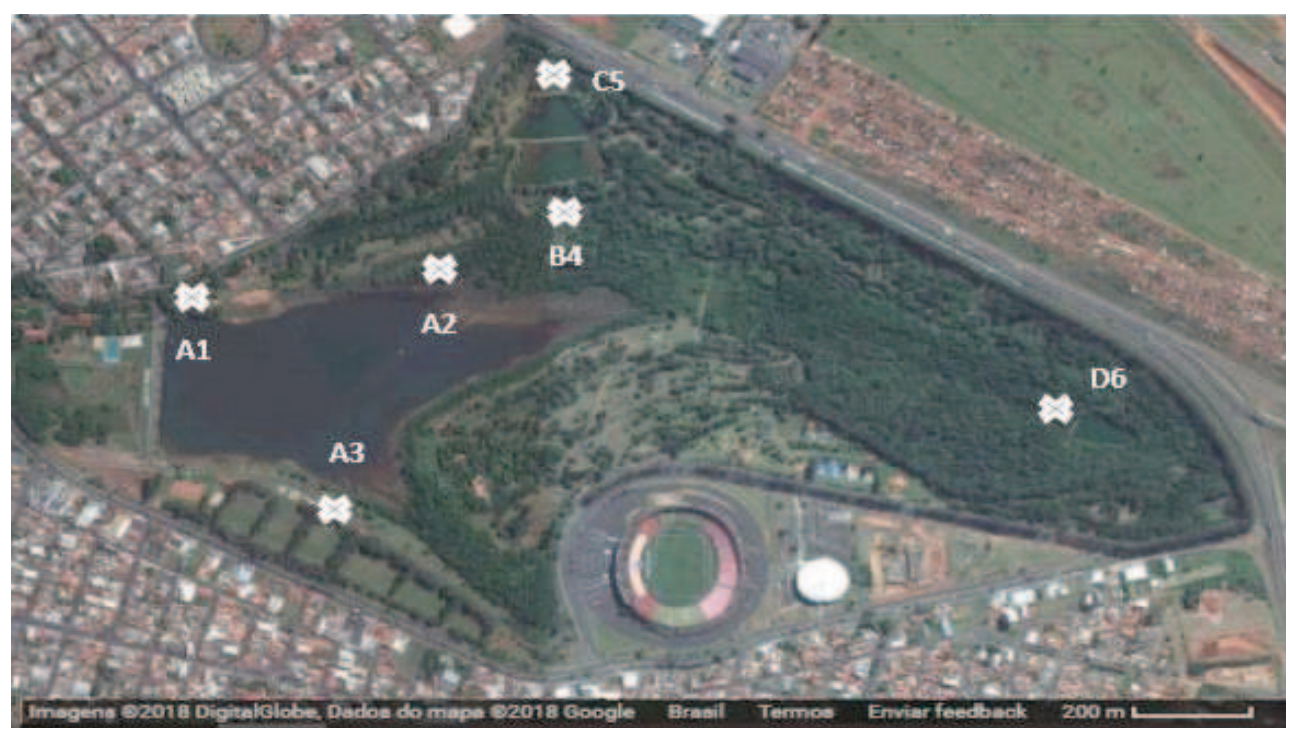


Climatology Laboratory at the Federal University of Uberlândia, Uberlândia, MG.

In total, 15 behavioral acts were analyzed and grouped, a posteriori, into the following categories: Vocalization (vocalizing); Flight (flight over perch, individual flight, flock flight); Maintenance (preening, scratching, drying, defecating, lying down, perching on the pond bank, and perching); and Foraging (lurking, diving, swimming, and entering the pond) (Table 1). The scratching and drying behaviors, in the Maintenance category, as well as entering the pond, swimming and diving, in the Foraging category, had the running time recorded in seconds using a stopwatch. The other behaviors were counted, based on their occurrence or not per individual during each watch, to elaborate on the repertoire and quantify the behavioral acts. This procedure was performed with the behaviors vocalizing, flight over perch, individual flight, flock flight, preening, defecating, lying down, perching, perching on the pond bank, and lurking. The frequency of each behavior was calculated based on all the records made during a session, with the watch time divided between individuals, considering a minimum time of 5 minutes per individual.

\section{Data analysis}

For behavioral acts, possible differences between ponds and the dry and rainy seasons were evaluated using a chi-squared test. The Kruskal-Wallis test was used to verify possible differences in landing height between ponds, with the greatest number of records of this behavior at points A1, A2, and A3. The Spearman correlation was used to evaluate the possible relation between the time spent by $N$. brasilianus drying its wings with rainfall and the temperature at the ponds where

TABLE 1: Categories and behavioral acts of Nannopterum brasilianus in ponds at Sabiá Municipal Park (Uberlândia, MG).

\section{Category \\ Behavioral Act \\ Description}

\section{Vocalization}

1. Vocalizing

To emit a sound similar to a grunt.

It can be done by an individual or by a flock.

\section{Flight}

1. Flight over perch

2. Individual flight

3. Flock flight

\section{Maintenance}

1. Preening

2. Scratching

3. Drying

4. Defecating

5. Lying down

6. Perching on the pond bank

7. Perching

\section{Foraging}

1. Lurking

2. Diving

3. Swimming

4. Entering the pond
To fly near the resting place once or more and return to the same place.

It can be done by an individual or by a flock.

To fly individually after resting.

To fly with the flock after resting.

With the beak on the plumage, to gently move the head from the base of the feather to its tip, cleaning it.

To scratch the crown with nails on one foot.

To dry the plumage by opening the tail and extending the wings, with a stretched neck.

To eliminate stool while standing.

To lean the chest against the base of an artificial structure to rest and observe.

To alight on the bank near the water area to observe.

To align the feet on an artificial or natural structure during rest and observation.

To stretch the neck towards the water and closely observe the movement of fish moments before fishing.

To dive for fish (at varying intervals).

Body semi-submerged in the water.

Walk towards and then enter the water, with a semi-submerged body, and spend non-fixed intervals of time before diving. 
the behavior was recorded (points A2 and A3). The Mann-Whitney test was used to verify if there was any difference in the duration of the drying wings behavior over the seasons in the same ponds. The analyses were performed with the programs Systat 10.2 (SPSS, 2002) and Statistica 7.0 (STATSOFT, Inc. 2004). All tests considered the level of significance $\mathrm{p}<0.05$ (ZAR, 1999).

\section{Results}

We made 164 behavioral records of $N$. brasilianus. Most of them were related to the Maintenance category (72.93\%), notably perching and preening (30.87 and $29.53 \%$, respectively). The most intense acts were scratching (3.54 \pm 5.87 times per minute of observation) and preening ( $1.64 \pm 0.86$ times per minute). Preening accounted for $27.87 \%$ of the behavioral acts recorded in the dry season and $31.53 \%$ in the rainy season. Perching accounted for $29.92 \%$ and $32.02 \%$ of the acts in the dry and rainy seasons, respectively. The Foraging category (and its respective acts) was carried out more often during the dry season (16.80\%) (Table 2). During foraging, the average time of diving was $7.84 \pm 4.59$ seconds and the average time of swimming was $31.79 \pm 35.68$ seconds.

For pound A (A1, A2 and A3), the most frequent category was Maintenance, corresponding to $88.46 \%$ of the acts in the rainy season (A1) and $92.31 \%$ in the dry season (A3). Within this category, preening was the most common act, $42.86 \%, 30.42 \%$ and $41.94 \%$

TABLE 2: Behavioral repertoire of Nannopterum brasilianusin at Sabiá Municipal Park per studied pond (A1, A2, A3, B4, C5 and D6 points) per season (dry and rainy) (30h40 min/point in observation). The numbers indicate the relative frequency (percentage) of acts and behavioral categories.

\begin{tabular}{|c|c|c|c|c|c|c|c|c|c|c|c|c|c|c|c|c|c|}
\hline Category & PondA1 & Rainy & Dry & PondA2 & Rainy & Dry & PondA3 & Rainy & Dry & PondB4 & Dry & PondC5 & Rainy & Dry & Rainy & Dry & $\begin{array}{c}\text { Grand } \\
\text { Total }\end{array}$ \\
\hline $\begin{array}{l}\text { Vocalization } \\
(\mathrm{n}=5)\end{array}$ & 0.00 & 0.00 & 0.00 & 1.51 & 2.53 & 0.57 & 0.00 & 0.00 & 0.00 & 0.00 & 0.00 & 0.00 & 0.00 & 0.00 & 1.97 & 0.41 & 1.12 \\
\hline 1. Vocalizing & 0.00 & 0.00 & 0.00 & 1.51 & 2.53 & 0.57 & 0.00 & 0.00 & 0.00 & 0.00 & 0.00 & 0.00 & 0.00 & 0.00 & 1.97 & 0.41 & 1.12 \\
\hline Flight $(n=66)$ & 9.52 & 11.54 & 6.25 & 18.37 & 20.25 & 16.67 & 9.68 & 11.11 & 7.69 & 0.00 & 0.00 & 0.00 & 0.00 & 0.00 & 18.23 & 12.70 & 15.22 \\
\hline $\begin{array}{l}\text { 1. Flight over } \\
\text { perch }\end{array}$ & 0.00 & 0.00 & 0.00 & 3.01 & 1.27 & 4.60 & 0.00 & 0.00 & 0.00 & 0.00 & 0.00 & 0.00 & 0.00 & 0.00 & 0.99 & 3.28 & 2.24 \\
\hline $\begin{array}{l}\text { 2. Individual } \\
\text { flight }\end{array}$ & 9.52 & 11.54 & 6.25 & 5.72 & 4.43 & 6.90 & 9.68 & 11.11 & 7.69 & 0.00 & 0.00 & 0.00 & 0.00 & 0.00 & 5.91 & 5.74 & 5.82 \\
\hline 3. Flock flight & 0.00 & 0.00 & 0.00 & 9.64 & 14.56 & 5.17 & 0.00 & 0.00 & 0.00 & 0.00 & 0.00 & 0.00 & 0.00 & 0.00 & 11.33 & 3.69 & 7.16 \\
\hline $\begin{array}{l}\text { Maintenance } \\
(\mathrm{n}=1.982)\end{array}$ & 88.10 & 88.46 & 87.50 & 78.61 & 75.95 & 81.03 & 90.32 & 88.89 & 92.31 & 0.00 & 0.00 & 0.00 & 0.00 & 0.00 & 78.33 & 68.44 & 72.93 \\
\hline 1. Preening & 42.86 & 42.31 & 43.75 & 30.42 & 28.48 & 32.18 & 41.94 & 44.44 & 38.46 & 0.00 & 0.00 & 0.00 & 0.00 & 0.00 & 31.53 & 27.87 & 29.53 \\
\hline 2. Scratching & 0.00 & 0.00 & 0.00 & 2.41 & 1.27 & 3.45 & 0.00 & 0.00 & 0.00 & 0.00 & 0.00 & 0.00 & 0.00 & 0.00 & 0.99 & 2.46 & 1.79 \\
\hline 3. Drying & 0.00 & 0.00 & 0.00 & 3.61 & 5.06 & 2.30 & 6.45 & 0.00 & 15.38 & 0.00 & 0.00 & 0.00 & 0.00 & 0.00 & 3.94 & 2.46 & 3.13 \\
\hline 4. Defecating & 2.38 & 3.85 & 0.00 & 2.71 & 0.63 & 4.60 & 0.00 & 0.00 & 0.00 & 0.00 & 0.00 & 0.00 & 0.00 & 0.00 & 0.99 & 3.28 & 2.24 \\
\hline 5. Lying down & 0.00 & 0.00 & 0.00 & 0.30 & 0.00 & 0.57 & 0.00 & 0.00 & 0.00 & 0.00 & 0.00 & 0.00 & 0.00 & 0.00 & 0 & 0.41 & 0.22 \\
\hline $\begin{array}{l}\text { 6. Perching on } \\
\text { the pond } \\
\text { bank }\end{array}$ & 0.00 & 0.00 & 0.00 & 3.01 & 6.33 & 0.00 & 41.94 & 44.44 & 38.46 & 0.00 & 0.00 & 0.00 & 0.00 & 0.00 & 8.87 & 2.05 & 5.15 \\
\hline 7. Perching & 42.86 & 42.31 & 43.75 & 36.14 & 34.18 & 37.93 & 0.00 & 0.00 & 0.00 & 0.00 & 0.00 & 0.00 & 0.00 & 0.00 & 32.02 & 29.92 & 30.87 \\
\hline $\begin{array}{l}\text { Foraging } \\
(\mathrm{n}=48)\end{array}$ & 2.38 & 0.00 & 6.25 & 1.51 & 1.27 & 1.72 & 0.00 & 0.00 & 0.00 & 100.00 & 100.00 & 100.00 & 100.00 & 100.00 & 0.49 & 16.80 & 10.73 \\
\hline 1. Lurking & 2.38 & 0.00 & 6.25 & 1.51 & 1.27 & 1.72 & 0.00 & 0.00 & 0.00 & 0.00 & 0.00 & 0.00 & 0.00 & 0.00 & 0.99 & 1.64 & 1.34 \\
\hline 2. Diving & 0.00 & 0.00 & 0.00 & 0.00 & 0.00 & 0.00 & 0.00 & 0.00 & 0.00 & 0.00 & 0.00 & 46.34 & 0.00 & 47.50 & 0 & 7.79 & 4.25 \\
\hline 3. Swimming & 0.00 & 0.00 & 0.00 & 0.00 & 0.00 & 0.00 & 0.00 & 0.00 & 0.00 & 0.00 & 0.00 & 46.34 & 0.00 & 47.50 & 0 & 7.79 & 4.25 \\
\hline $\begin{array}{l}\text { 4. Entering the } \\
\text { pond }\end{array}$ & 0.00 & 0.00 & 0.00 & 0.00 & 0.00 & 0.00 & 0.00 & 0.00 & 0.00 & 100.00 & 100.00 & 7.32 & 100.00 & 5.00 & 0.49 & 1.23 & 0.89 \\
\hline Total & 100 & 100 & 100 & 100 & 100 & 100 & 100 & 100 & 100 & 100 & 100 & 100 & 100 & 100 & 100 & 100 & 100 \\
\hline
\end{tabular}


of the behaviors exhibited at the A1, A2 and A3 points, respectively. Perching on the pond bank was predominant at point A3, accounting for $44.44 \%$ of the behaviors during the rainy season. Perching was predominant at both the A1 (43.75\%) and A2 (37.93\%) points during the dry season (Table 2).

At point A2, the species performed the greatest variety of behavioral acts (12 of the 15) within the four behavioral categories evaluated $\left(\chi^{2}=731.91, \mathrm{df}=56\right.$, $\mathrm{p}<0.0001)$. There was a higher number of individuals resting on perches at greater heights at point $\mathrm{A} 2$, where the most frequent height was $5 \mathrm{~m}$ (range of 3 to $7 \mathrm{~m}$ ), followed by point $\mathrm{A} 1$, which had a mean height of $3.5 \mathrm{~m}$ (range of 2 to $4.5 \mathrm{~m}$ ) (Figure 2). The perching height of $N$. brasilianus did not differ between dry and rainy seasons $\left(\mathrm{U}=40.5, \mathrm{n}_{\text {dry }}=10, \mathrm{n}_{\text {rainy }}=10, \mathrm{p}=0.46\right)$. The behaviors showed variations between the seasons $\left(\chi^{2}=62.05, \mathrm{df}=14, \mathrm{p}<0.001\right)$. Flock flight and perching on the pond bank were exhibited the most in the rainy season (11.33\% and $8.87 \%$, respectively). For preening, perching and individual flight, $N$. brasilianus showed a similar frequency for the two seasons (Table 2).

The drying behavior showed no correlation with rainfall $\left(\mathrm{r}_{\mathrm{s}}=-0.159 ; \mathrm{n}=20 ; \mathrm{p}>0.05\right)$ or temperature $\left(r_{s}=-0.313 ; n=20 ; p>0.05\right)$. The average duration of this behavior was $28.71 \pm 25.95$ seconds and it did not differ between seasons $\left(\mathrm{U}=37.0 ; \mathrm{n}_{\mathrm{dry}}=10 ; \mathrm{n}_{\text {rainy }}=10\right.$; $\mathrm{p}=0.32$ ).

No agonistic interactions were recorded between the species studied and other water birds observed in the study area, which were the following: anhinga (Anhinga anhinga), great egret (Ardea alba), cocoi heron (Ardea cocoi), striated heron (Butorides striata), snowy egret (Egretta thula), ringed kingfisher (Megaceryle torquata), black-crowned night heron (Nycticorax nycticorax), and rufescent tiger heron (Tigrisoma lineatum).

\section{Discussion}

The most frequent behavioral acts of $N$. brasilianus in Sabiá Park involved perching and preening, both from the Maintenance category. The first activity of $N$. brasilianus in the morning is rest, followed by drying and maintenance of the plumage to remove residues aggregated on the feathers during fishing and swimming (BRANCO et al., 2009). For birds, caring for their plumage is an important behavior, especially for water birds that need to arrange and dry their feathers more often after being in the water (SICK, 1997). For $N$. brasilianus, this behavior is even more relevant, since the

FIGURE 2: Resting height on perch (meters) per point of Nannopterum brasilianus. Smaller squares indicate the mean value of the data, the box represents the standard error, and bars (vertical lines) indicate the value of the standard deviation.

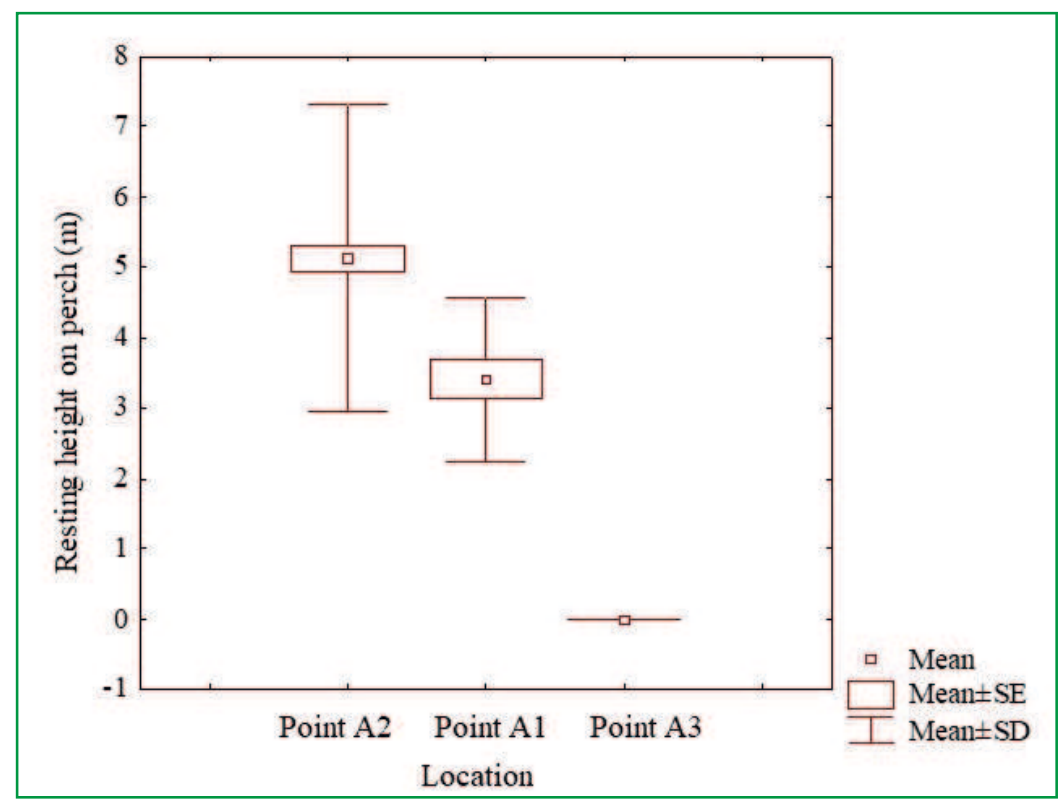


species has an underdeveloped uropygial gland, which leads to feathers becoming more easily soaked during foraging (STILES; SKUTCH, 2007). Perhaps this is the reason the maintenance acts exhibited similar patterns during the seasons and among the occurrence points of the species. Another important behavior recorded for the species was foraging, which was observed only a few times in the dry season. In most studies involving waterfowl, the Neotropic cormorant is one of the most abundant species and often exhibits individual or group foraging (BRANCO et al., 2009; RIBEIRO; FERREIRA, 2014). In this study, the records of this behavior were restricted to one pond (point C5), with foraging individuals, possibly due to the size of the pond. Branco (2007) and Carvalho (2010) recorded individual foraging by $N$. brasilianus in smaller ponds in parks, which are suitable for swimming and diving for food compared to group foraging within a small aquatic environment.

The smallest numbers of records of $N$. brasilianus were observed in the rainy season (especially in February, March and April), which coincides with the reproductive period of the species that is between December and February (SICK, 1997). In Rio Grande (RS), Neotropic cormorants migrate to other places by the end of March, April and May, resulting in a decrease in the number of individuals of the species in this period (BARQUETE et al., 2008). In the northern portion of the Amazon basin, in a stretch of the Amazon River in the state of Amapá, N. brasilianus exhibited a uniform pattern of fluctuation in numbers, with a gradual reduction starting in January and reaching the lowest average numbers between April and June (SILVA et al., 2014). Therefore, considering the mobility and migratory behavior of the species (GWYNNE et al., 2010), this research seems to suggest that $N$. brasilianus migrates to more appropriate places during the reproductive period and then returns to Sabiá Municipal Park for feeding, rest, and other daily activities. It is important to take into account the fact that not all individuals of a migratory species move during migration; instead, they form the resident or stationary population (ANDRADE, 1997), which explains the occurrence of the species throughout the year in the park. Furthermore, the nuptial plumage, consisting of white feathers on the head and neck (GWYNNE et al.,
2010), was not present on the observed individuals and no reproductive events were recorded. Nevertheless, $N$. brasilianus showed no relation with temperature and rainfall, which indicates the need for further studies to address this matter.

The greatest use of perches by $N$. brasilianus was observed at point A2, where the highest artificial perches (average of $5 \mathrm{~m}$ ) were recorded. Moreira and MarçalJunior (2014) reported that $N$. brasilianus extensively explores tall trees that exceed 8 meters, on Uberabinha River in Uberlândia (MG), and prefers trees with more open canopies. The preference for taller, leafless branches on the edges of treetops seems to indicate that these substrates favor maintenance activities, including drying feathers, which would increase the chances of returning to the same location to land and sleep. Our results corroborate this hypothesis. However, at Lagoa dos Patos (RS) N. brasilianus perches at different heights on energy towers over $130 \mathrm{~m}$ tall; however, it prefers lower heights, which may be associated with less exposure to wind (BARQUETE et al., 2008).

The non-occurrence of agonistic interactions between $N$. brasilianus and other water birds seems to reflect the high level of specialization of these species. Indeed, water birds have different foraging methods; for example, ringed kingfishers (Megaceryle torquatus, Chloroceryle amazona) stand on perches on bushes nearby the water waiting for the opportunity to catch their prey, whereas the anhinga (Anhinga anhinga) takes long dives in lakes (CARVALHO, 2010). The predation tactic of the Neotropic cormorant is even more distinct; it acts based on disturbances on the water surface, diving subsequently to capture the prey. This possibly reinforces that these species do not closely compete for resources in the ponds (SICK, 1997).

Birds tend to improve their tactics to explore for resources. They can compensate foraging time by distinguishing size and color of prey, or they distinguish subtle differences in the foraging environment. Mahendiran (2016), in a study in the region of Delhi, India, involving three sympatric species of Phalacrocorax spp. (P. niger, P. fuscicollis, P. carbo), showed that habitats exert a strong influence on the temporal distribution of prey. When $P$. niger and 
P. fuscicollis selected the same habitats, there was segregation in the foraging time; however, the result was the opposite for $P$. niger and $P$. carbo, indicating a partition of resources to minimize competition. Distinct niches facilitate ecological diversification through coexistence, avoiding direct confrontation (interference competition) or a reduction in resource overlap (competition for resources). This kind of information, combined with the fact that we did not record agonistic events or behavioral responses to the presence of other piscivorous birds, reinforces that it is possible that other piscivorous species found in the studied park do not directly compete with $N$. brasilianus.

The importance of parks for birds lies in the fact that these places are like vegetation corridors, which are essential for the maintenance of these animals in urban areas (ARGEL-DE-OLIVEIRA, 1996). Thus, parks and green spaces represent "refuges" for animals in the face of the pressures of urbanization and degradation of natural environments (MATARAZZO-NEUBERGER, 1995).

The occurrence of N. brasilianus in Sabiá Municipal Park during the entire investigated period indicates that the species finds the conditions of this environment favorable for its maintenance, mainly due to the plentiful marginal vegetation and the presence of artificial perches. Nonetheless, it appears that this area lacks the appropriate conditions for the reproductive period of $N$. brasilianus and the natural perches this species prefers. The behavioral repertoire of $N$. brasilianus is complex and the behaviors that were most exhibited outside the water, mainly outside the reproductive period, are associated with maintenance (perching and preening). Furthermore, there were no differences between the dry and rainy seasons for the observed behavioral acts, which reinforces that climatic conditions of the region are favorable for the behaviors.

\section{References}

ALTMANN, J. Observational study of behavior: sampling methods. Behaviour, Groningen, v. 49, n. 3, p. 227-267, 1974.

ANDRADE, M. A. de. Aves silvestres, Minas Gerais. Belo Horizonte: Editora Conselho Internacional para Preservação das Aves, 1997. 176 p.
ANJOS, L. A eficiência do método de amostragem por pontos de escuta na avaliação da riqueza de aves. Revista Brasileira de Ornitologia, Belém, v. 15, n. 2, p. 239-243, 2007.

ARAÚJO, G. M.; NUNES, J. J.; ROSA, A. G.; RESENDE, E. J. Estrutura comunitária de vinte áreas de cerrado residuais no município de Uberlândia, MG. Daphne, Belo Horizonte, v. 7, n. 2, p. 7-14, 1997.

ARGEL-DE-OLIVEIRA, M. M. Subsídios para a atuação de biólogos em Educação Ambiental. $\mathrm{O}$ uso de aves urbanas em educação ambiental. O Mundo da Saúde, São Paulo, v. 20, n. 8, p. 263-270, 1996.

BARQUETE, V.; VOOREN, C. M.; BUGONI, L. Seasonal abundance of the Neotropic Cormorant (Phalacrocorax brasilianus) at Lagoa dos Patos estuary, southern Brazil. El Hornero, Buenos Aires, v. 23, n. 1, p. 15-22, 2008.

BIBBY, C.; BURGESS, N.; HILL, D. Bird census techniques. London: Academic Press, 1992. 302 p.

BRANCO, J. O. Avifauna aquática do Saco da Fazenda (Itajaí, Santa Catarina, Brasil): uma década de monitoramento. Revista Brasileira de Zoologia, Curitiba, v. 24, n. 4, p. 873-882, 2007.

BRANCO, J. O.; EVANGELISTA, C. L.; LUNARDONBRANCO, M. J.; AZEVEDO JÚNIOR, S. M.; LARRAZÁBAL, M. E. de. Atividade di ria de Phalacrocorax brasilianus (Aves, Phalacrocoracidae), na região do Saco da Fazenda, Itajaí, SC, Brasil. Ornithologia, Cabedelo, v. 3, n. 2, p. 73-82, 2009.

CARVALHO, F. F. Comportamento Alimentar das Aves Piscívoras Aquáticas do Parque Natural "Chico Mendes". Revista Eletrônica de Biologia, Sorocaba, v. 3, n. 2, p. 11-19, 2010.

DEL CLARO, K. Técnicas de amostragem e observação animal. In: DEL CLARO, K. (Ed.). Comportamento animal - Uma introdução à ecologia comportamental. Jundiaí: Livraria Conceito, 2004. p. 79-86.

FERNÁNDEZ-JURICIC, E.; TELLERÍA, J. L. Effects of human disturbance on Blackbird Turdusmerula spatial and temporal feeding patterns in urban parks of Madrid. Bird Study, London, v. 15 , p. 373-383, 2000.

FRANCHIN, A. G.; MARÇAL JÚNIOR, O. A riqueza da avifauna no Parque Municipal do Sabiá, zona urbana de Uberlândia (MG). Biotemas, Florianópolis, v. 17, n. 1, p. 179-202, 2004.

GUIBU, S. D.; MONTEIRO, L. M. O; MARTINS, M.; ANJOSAQUINO, E. A. C.; ALBUQUERQUE, L. B. Aves da Lagoa Itatiaia: distribuição espacial e comportamento. Multitemas, Campo Grande, v. 23, n. 35, p. 7-42, 2007.

GWYNNE, J. A.; RIDGELY, R. S.; TUDOR, G.; ARGEL, M. Guia aves do Brasil: Pantanal e Cerrado. Vol. 1. São Paulo: Editora Horizonte, 2010. 336 p.

HÖFling, E.; CAMARGO, H. F. A. Aves no Campus. 3 ed. São Paulo: Editora da Universidade de São Paulo, 1999. 168 p.

IBGE - INSTITUTO BRASILEIRO DE GEOGRAFIA E ESTATÍSTICA. Minas Gerais. Uberlândia. População Estimada 2017. Uberlândia, 2017. Disponível em: <https://cidades.ibge.gov. $\mathrm{br} / \mathrm{brasil} / \mathrm{mg} / \mathrm{uberlandia/panorama}>$.

MAFIA, P. de O.; OLIVEIRA, E. G. de.; BARÇANTE, L. Avifauna do Parque Municipal Fazenda Lagoa do Nado, Belo Horizonte, 
Minas Gerais. Atualidades Ornitológicas, Ivaiporã, n. 165, p. 33 39, 2012.

MAHENDIRAN, M. Coexistence of three sympatric cormorants (Phalacrocorax spp.); Partitioning of time as an ecological resource. Royal Society Open Science, London, v. 3, n. 5, p. 160-175, 2016.

MATARAZZO-NEUBERGER, W. M. Comunidades de cinco parques e praças da Grande São Paulo, Estado de São Paulo. Ararajuba, Londrina, v. 3, n. 1, p. 13-19, 1995.

MAURER, B. A. Extensions of optimal foraging theory for insectivorous birds: implications for community structure. In: MORRISON, M. L.; RALPH, C. L.; VERNER, J.; JEHL Jr., J. R. (Ed.). Avian foraging: theory, methodology and applications. Lawrence: Cooper Ornithological Society (Studies in Avian Biology 13), 1990. p. 455-461.

MØLLER, A. P.; IBÁÑEZ-ÁLAMO, J. D. Escape behaviour of birds provides evidence of predation being involved in urbanization. Animal Behaviour, London, v. 84, n. 2, p. 341-348, 2012.

MOREIRA, S. G.; MARÇAL JÚNIOR, O. Fatores ambientais e atividades humanas associados à distribuição de aves aquáticas na rea urbana de Uberlândia - MG. CERRADO Agrociências, Patos de Minas, v. 5, p. 1-12, 2014.

PMU - PREFEITURA MUNICIPAL DE UBERLÂNDIA. Secretaria do Meio Ambiente e Desenvolvimento Urbanístico. Complexo Parque do Sabia. Uberlândia, 2014. Disponível em: $<$ http://www.uberlandia.mg.gov.br/2014/secretaria-pagina/51/144/ secretaria.html>.

RIBEIRO, M. A. M.; FERREIRA, R. C. Riqueza e distribuição das aves aquáticas do Parque do Carmo - Olavo Egydio Setúbal, São Paulo, Brasil. Enciclopédia Biosfera, Goiânia, v. 10, n. 18, p. 3380-3391, 2014.
RICKLEFS, R. A. Economia da natureza. 7. ed. Rio de Janeiro: Guanabara Koogan, 2016. 572 p.

ROSA, R.; LIMA, S. C.; ASSUNÇÃO, W. L. Abordagem preliminar das condições climáticas de Uberlândia (MG). Sociedade e Natureza, Uberlândia, v. 3, n. 1, p. 91-108, 1991.

SICK, H. Ornitologia brasileira. Rio de Janeiro: Nova Fronteira, 1997. 912 p.

SILVA, E. F.; NAIFF, R. H.; BARATA, F. D. B.; SANTOS JÚNIOR, L. S.; FRANÇA, P. F.; CAMPOS, C. E. C. Abundância sazonal de Phalacrocorax brasilianus (Gmelin, 1789) (Aves, Phalacrocoracidae) na Porção Norte da Bacia Amazônica, Macapá, Amap , Brasil. Biota Amazônia, Macap , v. 4, n. 2, p. 64-67, 2014. SHERER, J. de F. M.; SCHERER, A. L.; PETRY, M. V. Estrutura trófica e ocupação de hábitat da avifauna de um parque urbano em Porto Alegre, Rio Grande do Sul, Brasil. Biotemas, Florianópolis, v. 23, n. 1, p. 169-180, 2010. SPSS, Inc. Systat Sofware. Version 10.2. 2002 .

STATSOFT, Inc. Statistica (data analysis software system). Version 7. 2004. Disponível em: <www.statsoft.com>.

STILES, F. G.; SKUTCH, A. F. Guia de aves de Costa Rica. 4. ed. Heredia: Instituto Nacional de Biodiversidade, 2007. 572 p.

TELINO JÚNIOR, W. R.; AZEVEDO JÚNIOR, S. M. de; NEVES, R. M. de L. Biologia e censo Porphyrula martinica, Ganninula chloropus e Jacana jacana em Dois Irmãos, Pernambuco, Brasil. Lundiana, Belo Horizonte, v. 4, n. 1, p. 43-49, 2003.

ZAR, J. H. Biostatistical analysis. New Jersey, Prentice Hall, 1999. $663 \mathrm{p}$. 